This is a pre-copy-editing, author-produced PDF of an article accepted for publication in History Workshop Journal following peer review. The definitive publisher-authenticated version "Detective Fiction in the Archives: Court Records and the Uses of Law in Late Medieval England," History Workshop Journal 65 (Spring 2008), 65-78, is available online at: http://hwj.oxfordjournals.org/cgi/reprint/65/1/65 or http://0hwj.oxfordjournals.org.mercury.concordia.ca/cgi/reprint/65/1/65

\title{
Detective Fiction in the Archives: Court Records and the Uses of Law in Late Medieval England
}

Shannon McSheffrey

Historians are often compared to detectives, searching for clues and uncovering connections until at last the truth is found and the mystery is solved. ${ }^{1}$ The fictional detective works the streets and the historian works the archives, but the process of building a case and of making logical inferences from scattered clues is sometimes remarkably similar. Historians, however, are no longer permitted the certainty that marked the conclusions of classic detective fiction: we are rarely, if ever, sure anymore about who dunnit (whatever 'it' might be) or why. This constant epistemic doubt can be

I am grateful for the help and advice on this article offered by Kit French, Evan May, Elena Razlogova, Eric Reiter, Ron Rudin, and the reviewers for this journal.

Note: Spelling in quotations in Middle English are modernized, with the original in the footnote when appropriate; modernizations and translations from Latin sources are my own.

${ }^{1}$ See, for instance, Robin Winks, ed., The Historian as Detective, New York, 1969. 
disorienting. On the one hand, many archival detectives, myself included, have, like our progenitor Jules Michelet, an essentially romantic sense that we can virtually see the dead through the dust of the document. The piece of parchment or paper, in some cases actually held by the hand of the person whom we are investigating, seems to create a literally tangible connection. ${ }^{2} \mathrm{On}$ the other hand, both theory and the practical problems of research warn us continually that this vision of the dead is a mirage, or at least a highly refracted image: each new clue can throw all previous evidence into completely new light, effectively changing the direction of the narrative running inside our heads.

My goal in this article is to explore two issues. The first is a problem in legal and social history: how did late medieval Londoners use the legal and archival powers of governing authorities in order to negotiate their lives? The second is a problem in historical methodology: how can thinking about the archives as historical agents rather than as inert repositories of evidence refine the way we use historical documents? Over the last several years, while working on the legal history of late medieval London, I have become interested in considering medieval legal history from the vantage point of the 'archival turn', an approach to working with archival sources influenced especially by Arlette Farge's Goût de l'archive and Jacques Derrida's Archive Fever. $^{3}$ Briefly stated, taking the archival turn demands that historians be more self-conscious not only about the meaning of the documents they study, but also about how the documents came to be archived in the first place, in whose interest they have been officially preserved, and how the documenting

\footnotetext{
${ }^{2}$ Jules Michelet, Histoire de la Révolution française, ed. Gérard Walter, Paris 1952, vol. 1, p. 14, cited in Carolyn Steedman, Dust, Manchester, 2001, p. 27.

3 Arlette Farge, Le goût de l'archive, Paris, 1989; Jacques Derrida, Mal d'archive: une impression freudienne, Paris, 1995, in English translation as Archive Fever: A Freudian Impression, translated by Eric Prenowitz, Chicago, 1996, esp. p. 4n on politics and the archive. Historians have, in using Derrida, often deliberately taken the 'archive' more literally than did Derrida himself. See Steedman, Dust (esp. pp. 1-12 on the literalness of the archive), and a recent essay collection which acts also as a guide to the literature: Archive Stories: Facts, Fictions, and the Writing of History, ed. Antoinette Burton, Durham, NC, 2005. See also Harriet Bradley, 'The Seductions of the Archive: Voices Lost and Found', History of the Human Sciences 12:2, 1999, pp. 107-22; Ann Laura Stoler, Carnal Knowledge and Imperial Power: Race and the Intimate in Colonial Rule, Berkeley, 2002, pp. 162 204; Jo Tollebeek, 'Turn'd to Dust and Tears': Revisiting the Archive', History and Theory 43, May 2004, pp. 237-48. My title pays homage to a foundational work in considering the narrative qualities of many legal documents: Natalie Zemon Davis's Fiction in the Archives: Pardon Tales and Their Tellers in Sixteenth-Century France, Stanford, 1987.
} 
of particular events and processes - and not others - serves to shape what is known about the past. Although scholarship in several fields of historical study, especially imperial and colonial history, has embraced the archival turn, as yet few pre-modernists have responded to it. ${ }^{4}$ Nonetheless those of us who use archives compiled before the rise of the modern state (the entity generally seen as responsible for the constitution of modern archives) can both benefit from the insights of this literature and offer useful critiques to the modernist assumptions embedded in this (post)modernist scholarship.

It is particularly useful to juxtapose the methods of the archival turn with an approach to legal history that Peter Coss has termed 'law in society'. Rather than focusing on the power of the state apparatus (the traditional emphasis of legal history), 'law in society' literature has underscored how law works through social interactions, with individuals effectively using the power of governing authorities and their laws to negotiate their lives. As E. P. Thompson famously asserted, law was at 'every bloody level' of social relations, deeply imbricated in their workings. ${ }^{6}$ The law and its archives were not infinitely malleable, of course; while those involved in legal processes wielded the law and the archive (understood broadly as any recording authority, be it royal, civic, or ecclesiastical), at the same time they had to operate within the framework the law established. If people used the law and the archive for their own purposes, in turn the law and the archive shaped or constrained people's choices and relationships.

A legal history lens is particularly suited to examining premodern archives, as most premodern archival documents are records of legal proceedings and transactions. Those documents cannot be seen only as reflections of the past, as witnesses to history, but must also be understood as agents in the historical process. Legal documents were not just inert and

\footnotetext{
${ }^{4}$ A notable exception is the special issue, entitled 'Fabrique des archives, fabrique de l'histoire', of Revue de synthèse 125, 2004.

${ }^{5}$ See, for premodern English legal history, Peter Coss, ed., The Moral World of the Law, Cambridge, 2000; Christopher Brooks and Michael Lobban (eds), Communities and Courts in Britain, 1150-1900, London, 1997; Anthony Musson, Medieval Law in Context: The Growth of Legal Consciousness from Magna Carta to the Peasants' Revolt, Manchester, 2001; Anthony Musson, ed., Expectations of the Law in the Middle Ages, Woodbridge, Suffolk, 2001. For premodern Europe more generally, see Daniel Lord Smail, The Consumption of Justice: Emotions, Publicity, and Legal Culture in Marseille, 1264-1423, Ithaca, 2003; Michael Goodich (ed), Voices from the Bench: The Narratives of Lesser Folk in Medieval Trials, Houndmills, 2006.

${ }^{6}$ E. P. Thompson, The Poverty of Theory and Other Essays, London, 1978, p. 288 (emphasis original).
} 
transparent accounts of a legal proceeding or act. These documents were written precisely because they were meant to do something, to be, at least potentially, performative, or because they might later be called upon, either by the recording authorities or by the parties involved, to demonstrate that particular people did something in a particular way at a particular time and place. Accordingly the way documents were recorded was subject to the various interests of the parties involved and the recording authorities. ${ }^{7}$ At the same time, legal archives also include documents that recorded what someone thought should happen, hoped would happen, wanted to pretend had happened - and yet sometimes had not happened at all, or at least not as recorded in the document. In being archived, however, those aspirational documents in a sense become what happened.

In this article I will tease out these issues through a microhistorical examination of a late medieval English marriage case involving two Londoners named Joan Stokton Turnaunt and Richard Turnaunt. In doing so, I hope to shed light not only on what documents meant and mean, but also on law and legal processes, the point of connection between many of those documents and the world in which they were recorded and used. In the circumstances surrounding the Turnaunt case, someone manipulated the processes of law, using the authority and perceived truthfulness of the legal record - the power of the archive - to perpetrate a falsity. Documents (and the inferences we can draw from them) concerning the life stories of Joan Stokton and Richard Turnaunt invites us to broaden this analysis even further, to consider how legal and archival mechanisms intersected not only with rational strategies of social negotiation, but also with the irrational and the emotional.

In 1469, the records of the Consistory court of the diocese of London indicate that Joan Stokton alias Turnaunt sued for divorce a vinculo (or what

\footnotetext{
7 The classic account of the development of the documentary record, and the ways in which documents were used and understood a century or more before the period under consideration here, is Michael Clanchy's From Memory to Written Record: England 1066-1307, $2^{\text {nd }}$ ed., Oxford, 1993. Smail, in Consumption of Justice, esp. pp. 207-41, uses a different approach to discuss the development of the medieval archive in a legal culture quite distinct from England's.
} 
we would call an annulment) from her husband Richard Turnaunt. ${ }^{8}$ The basis for the annulment was a previous marriage she had contracted with another man, John Colyn, in about 1445, twenty-four years before. This previous union made her 1458 marriage with Richard Turnaunt bigamous and therefore null. The testimony recorded in the case was straightforward and the annulment was probably granted. ${ }^{9}$ As we will see, however, inconsistencies and anomalies in the evidence raise doubts about what the documents in this case actually tell us.

Joan Stokton came from and married into wealthy and prominent families, and she and her family members have left a number of traces in other fifteenth-century legal and government records. Together with the marriage case, these records allow us to weave together something of a reconstruction of her life. Joan was the daughter of John Stokton, a prominent mercer, alderman, and (in the year following his daughter's divorce) Lord Mayor of London. When he died in 1473 he left a significant fortune and was likely one of the wealthiest men in London. ${ }^{10}$ In the 1440 s, when our story begins, John Stokton was already active as an international merchant, ${ }^{11}$ and Joan was probably his eldest child. In the colourfully detailed story told in 1469 by the witnesses to her divorce suit, Joan Stokton and John Colyn had exchanged vows of present consent (that is, binding vows of

${ }^{8}$ London Metropolitan Archives, MS DL/C/205, Consistory Court of the Diocese of London Deposition Book 1467-76 [hereafter LMA, MS DL/C/205], fols. 45v-47v.

9 The court's judgement and sentence do not survive. I have inferred that the annulment was granted based on the straightforward(-seeming) evidence, the lack of contestation of the suit, and Joan's father's 1471 will which implies that Joan is no longer married to Richard (see below, n. 33).

${ }^{10}$ See Sylvia L. Thrupp, The Merchant Class of Medieval London, 1300-1500 Ann Arbor, 1962, p. 368. The date of his death is fixed by a writ of diem clausit extremum (triggering an inquisition post mortem) issued on death of John Stokton, knight, of Bucks., Essex, and Herts., 10 May 1473. Calendar of the Fine Rolls... 1471-85, London, 1961, p. 59. Although he left a very considerable estate on his death (about £8300), his widow Elizabeth Stokton and her subsequent husband Gerard Canizian could not administer the provisions of his will, and a good deal of chancery litigation resulted. See Kew, The National Archives [hereafter TNA], C 1/82/59, C 1/64/595, C 1/59/69, C 1/108/106, C 1/234/8, C 4/21/104; Will of John Stokton, 1473, PCC Prob. 11/6, fols. 71v75r; Laetitia Lyell and Frank D. Watney, Acts of the Court of the Mercers' Company, 1453-1527, Cambridge, 1936, pp. 77, 81, 99-100; Anne F. Sutton, The Mercery of London: Trade, Goods, and People, 1130-1578, Aldershot, 2005, p. 226.

${ }^{11}$ Reginald R. Sharpe, ed., Calendar of Letter-Books Preserved among the Archives of the Corporation of the City of London at the Guildhall, 11 vols., Letter Books G through L, London, 1899-1912, Letter Book K, p. 217; Calendar of the Patent Rolls... 1446-52, London, 1909, pp. 140, 186. 
marriage) twenty-four years before. ${ }^{12}$ On the Sunday before the feast of St. Bartholomew, late August 1445, the two witnesses were on their way to watch wrestling in Clerkenwell, on the outskirts of the city of London. Crossing St. Lawrence's Lane in the Jewry, they ran into John Colyn, standing in the lane at the doorway of John Stokton's house. John Colyn asked the two men to come up with him to the gallery of John Stokton's house to hear what would be said between him and Joan Stokton, John Stokton's daughter, who was then sitting on the highest step of the stairway leading to the gallery. There in the gallery the two men bore witness while John Colyn and Joan Stokton exchanged vows of present consent to marry and gave one another gifts. What happened after this exchange of consent is not recorded, but both witnesses testified that John Colyn was still alive, that he was living in Cambridge, and that they had each seen him at different times within the previous year. As the contract of marriage John and Joan had allegedly made was binding, they had all this time been married.

Joan, John Stokton's oldest surviving child at the time of his death, was likely very young in 1445; I suspect she was in her mid-teens, just as the two witnesses and possibly also John Colyn were. For the daughter of an up-andcoming mercer to make a contract of marriage with a man in the presence of only two adolescents, and in the absence of her father or any other guardian, would have been well outside the normal channels for the merchant elite of London in the fifteenth century. While marriages for daughters of the civic elite were usually not entirely arranged, as they often were for the aristocracy,

\footnotetext{
${ }^{12}$ By late medieval Catholic theology and canon law, the sacramental tie of marriage was created by the exchange of consent between the man and the woman, in England normally through formulaic words ('I take thee, Joan, to be my wedded wife'; 'I take thee John to be my wedded husband'). This could take place anywhere and any time, and no priest's presence or blessing was necessary. On the canon law of marriage in late medieval England, see Richard Helmholz, Marriage Litigation in Medieval England, Cambridge, 1974, and Michael M. Sheehan, Marriage, Family, and Law in Medieval Europe: Collected Studies, ed. James K. Farge, Toronto, 1996. For marriage in London, see Shannon McSheffrey, Marriage, Sex, and Civic Culture in Late Medieval London, Philadelphia, 2006. See also important work by Richard M. Wunderli, London Church Courts and Society on the Eve of the Reformation, Cambridge, Mass, 1981; Charles Donahue, Jr., 'The Canon Law on the Formation of Marriage and Social Practice in the Later Middle Ages', Journal of Family History 8, 1983, pp. 144-58; L. R. Poos, 'The Heavy-Handed Marriage Counsellor: Regulating Marriage in Some Later-Medieval English Local Ecclesiastical-Court Jurisdictions', American Journal of Legal History 39, 1995, 291-309; P. J. P. Goldberg, Women, Work, and Life Cycle in a Medieval Economy: Women in York and Yorkshire, c. 1300-1520, Oxford, 1992; Frederik Pedersen, Marriage Disputes in Medieval England London, 2000. For Europe more generally, see James A. Brundage, Law, Sex, and Christian Society in Medieval Europe, Chicago, 1987.
} 
marriage choices were nonetheless closely supervised and directed. ${ }^{13}$ I have not been able to trace John Colyn (a number of men had that name in London during the period in question, but none appears to fit), which itself suggests that he was not of a family and background that befitted a marriage to the daughter of John Stokton. The witnesses did not testify regarding what happened following the exchange of consent, but imply that the marriage was abandoned and that Joan Stokton and John Colyn went on to live separate lives.

Fourteen years later, in 1458, then likely about thirty years old and apparently not having married again in the meantime, Joan Stokton married Richard Turnaunt, a candidate much better suited to her status as the daughter of a prominent mercer. Richard, also aged about thirty in $1458,{ }^{14}$ was the son of a Winchester landowner. After his father's death in 1432, Richard's mother Joan married twice more, in both cases to prominent London merchants. As his second stepfather John Gedney had no children of his own, Richard Turnaunt ultimately became the heir, after his mother's death in 1462, to Gedney's manors in Tottenham, ${ }^{15}$ and it was as a Middlesex gentleman that Richard Turnaunt lived most of his adult life. Richard had been married previously, to a woman named Elizabeth who died in $1457,{ }^{16}$ although there were apparently no surviving children from that union. When Richard Turnaunt and Joan Stokton married in October 1458, the Tottenham manors were settled on the couple and the heirs of Richard's body, with John Stokton acting as one of the feoffees (trustees) of the manors. ${ }^{17}$ About 1459 or 1460 , Joan gave birth to a daughter, Thomasine, ${ }^{18}$

\footnotetext{
${ }^{13}$ See McSheffrey, Marriage, Sex, and Civic Culture, ch. 1 and 3.

${ }^{14}$ Daniel Lysons, The Environs of London: Being an Historical Account of the Towns, Villages and Hamlets, Within Twelve Miles of that Capital, 4 vols., London, 1792-1796, vol. 3, p. 526.

${ }^{15}$ Will of Joan Gedney, 1462, London, Guildhall Library [hereafter GL], MS 9171/5, fols. 327v$328 \mathrm{r}$.

${ }^{16}$ John Weever noted her funeral monument in Tottenham parish church, which read 'Orate ... Elizabeth Turnant uxoris Richardi Turnant Ar<miger>, que obit .... 1457'. John Weever, Ancient Funerall Monuments, London, 1631, p. 535.

${ }^{17}$ Letter patent issued 14 Oct. 1458; according to the witness in the Consistory Court divorce case, the two married a week later, 21 Oct. 1458. Calendar of the Patent Rolls...1452-61, London, 1910, pp. 474-75; LMA, MS DL/C/205, fol. 45v. Feoffments to use - the conveyance of lands to a group of trustees or feoffees who were honour-bound to hold them for the benefit of the feoffor - were commonly employed in the England in the late Middle Ages to circumvent legal restrictions on the conveyance of land.
} 
and apparently there were other children born in the first years of the marriage who died in infancy. ${ }^{19}$

A document suggests that by the mid 1460 s - if not before ${ }^{20}$ - there were serious problems with Richard's and Joan's marriage. About 1464, Richard Turnaunt sued his father-in-law John Stokton in Chancery, complaining that although he, Richard, 'many times and oft hath required the said John Stokton to release all his right and claim that he hath had, hath, or in time to come may have' as feoffee, John Stokton has nonetheless steadfastly refused to do so. Richard gives no reason for demanding that John Stokton relinquish his feoffeeship, except to say that 'good faith and conscience' require it. ${ }^{21}$ Whether as a result of the Chancery suit or other circumstances, Stokton did relinquish his claims as feoffee on the manors in March 1464. ${ }^{22}$ The licence confirming the new list of feoffees - same as the old list but without John Stokton - still listed Joan, daughter of John Stokton, as Richard Turnaunt's wife. ${ }^{23}$ In other words, officially the marriage was still extant, and Joan, if widowed, would have had a life interest in the property. Nonetheless, by 1464 hostility between Richard Turnaunt and his wife's family - perhaps also his wife - appears to have become serious. This inference is obviously given much more credibility by our knowledge that an uncontested suit for divorce was launched in 1469.

Superficially, Turnaunt c. Turnaunt was an uncomplicated bigamy case: Joan was already married when she solemnized her union with Richard

\footnotetext{
${ }^{18}$ Richard Turnaunt's inquisition post mortem states that she was 26 years old in 1486. Calendar of Inquisitions Post Mortem ... Henry VII, 3 vols., London, 1898-1955, vol. 1, pp. 80-81.

${ }^{19}$ GL, MS 9171/5, fol. 328r.

${ }^{20}$ In 1462, when Richard's dying mother, Joan Gedney, wrote her will, not only did she omit any mention of her daughter-in-law (which in itself would not have been unusual), but she also decreed that a particular piece of property should go, in the case of the deaths of Richard and Thomasine, his two-year-old daughter, to any other child Richard might have 'per aliquam mulierem legitime et in sponsalia ... procreandis [born to any woman legitimately and within marriage]'. This is an odd thing to say about a man who is already married to a woman of childbearing years and would normally have had every expectation of having more children with her. The will was dated 28 June 1462 and probated 10 July 1462, less than two weeks later. GL, MS 9171/5, fols. 327v-328r.

${ }^{21}$ TNA, C 1/28/50, 1462-64 (early date given by Joan Gedney's death, and likely early 1464, by evidence of Calendar of the Close Rolls...1461-68, London, 1940, p. 241).

${ }^{22}$ Calendar of the Close Rolls...1461-68, p. 241.

${ }^{23}$ The licence was dated 20 Mar. 1464; Calendar of the Patent Rolls... 1461-67, London, 1897, pp. $325-26$.
} 
Turnaunt, and sufficient witnesses were brought forward to testify to this. The witnesses delivered clear and precise testimony. No counter-evidence was introduced by Richard Turnaunt, who apparently did not oppose the case. The consistory court judge dissolved the marriage, apparently satisfied with the evidence.

But perhaps he should not have been: despite what seems a clear-cut case, a number of prickling anomalies in the depositions present themselves. The first is the possibility, indeed the likelihood, that the witnesses who claimed to have seen and heard Joan Stokton's first marriage to John Colyn were lying, and that indeed the first marriage, the basis of the divorce suit, was entirely invented. This spectre is raised by a spate of similar bigamy cases that were heard before the Consistory court between the time of the Turnaunt divorce in 1469 and 1474. In these suits, a suspiciously convenient long-ago contract, often to a person either subsequently deceased or whose whereabouts were unknown at the time of the suit, surfaced to be used as grounds to annul a later marriage. ${ }^{24}$ While some of these cases may have been genuine, of course, the clustering of this sort of suit in a five-year period suggests instead the discovery, and subsequent abandonment, of a convenient means of ending an inconvenient marriage.

In some of these bigamy cases between 1469 and 1474 the evidence for perjury is more direct. In 1471, for instance, Maude Radclyffe, a sixty-year-old widow, told the Consistory court that she was asked to testify falsely that she had been present twenty-two years before at a contract of marriage, on the strength of written 'proof' that the contract had taken place: she was shown a document, on which was written, in English, "'I, Thomas Weston, take you, Cecily, as my wife and thereto I give you my faith", and then Cecily said to him, "And I, Cecily, take you, Thomas, as my husband, and thereto I give you my faith"'. She said that the document also recorded that the said contract was celebrated on the Friday immediately after the middle Sunday of Lent, twenty-two years before. Maude, however, was less inclined to accept this documentary proof than those who attempted to induce her to perjury hoped, and instead she simply reported the subornation. ${ }^{25}$ In another of these cases, a

\footnotetext{
${ }^{24}$ See the cases listed below in n.29.

25 'Interrogata ulterius utrum nouit vel sciuit de aliquo contractu matrimoniali habito siue facto inter Ceciliam et Thomam Weston, dicit quod non interfuit in aliquo contractu habito inter dictos Ceciliam et Thomam Weston, nisi sub modo sequenti, videlicet quod una cedula erat coram ista iurata porrecta, in anglicis concepta, et per eandem perlecta, sub hiis verbis, "Ego Thomas Weston capio te Ceciliam in uxorem meam et ad hoc do tibi fidem meam", et tunc dicta Cecilia dixit
} 
witness later returned to the court to rescind his previous testimony, admitting instead that a man named Thomas Gryffyn had promised him forty shillings to testify that he had been present at the long-ago contract of marriage, when in fact he had not been. ${ }^{26}$ It surely cannot be coincidental that the same Thomas Gryffyn was one of the witnesses in Turnaunt c. Turnaunt ${ }^{27}$; this later accusation against him certainly casts significant doubt on his testimony about witnessing an exchange of consent between Joan Stokton and John Colyn in the gallery of her father's house in 1445. After 1474, bigamy cases based on long-ago-but-just-recently-remembered prior contracts disappear from the surviving records of London Consistory court litigation, suggesting that what had been a useful if mendacious legal strategem for ending an unwanted marriage was no longer successful at the Consistory court, possibly because judges were no longer willing to buy these stories. ${ }^{28}$ In 1469 , however, it could have worked, and in Turnaunt c. Turnaunt, I think it did.

But doubt about the veracity of the witnesses' account of the long-ago contract is not the only anomaly in the presentation of this divorce suit. Most often in cases of bigamy the plaintiff was the second spouse seeking to cast off the bigamous wife or husband. ${ }^{29}$ In this case, however, the suit was brought in

eidem, "Et ego Cecilia accipio te Thomam in maritum meum et ad hoc do tibi fidem meam". Et ulterius dicit quod erat scriptum in hac cedula quod dictus contractus erat celebratus in die veneris immediate precedente mediam dominicam quadragesime ultima preterita ad xxii annos elapso, et quod erat rogata ad deponendum quod erat presens illo die et huiusmodi contractum audiuit'. LMA, MS DL/C/205, fol. 100r.

${ }^{26}$ LMA, MS DL/C/205, fol. 181v.

${ }^{27}$ LMA, MS DL/C/205, fol. 47v. He may also be the same Thomas Gryffyn who had sued Isabel Ady alias Tomson in 1467 to enforce a contract of marriage. Ibid., fols. 8rv.

${ }^{28}$ Possibly the practice of introducing a fabricated first marriage in a bigamy suit was for a brief time a commonly-accepted legal fiction, similar to the common recovery (with the use of the 'common vouchee') developed around this time to bar entails (see Joseph Biancalana, The Fee Tail and the Common Recovery in Medieval England, 1176-1502, Cambridge, 2001, pp. 250-261, 284-90), or indeed to the practice of using professional co-respondents to produce evidence of adultery in twentieth-century divorce litigation in England and some American states (see Dorothy Dunbar Bromley, 'Perjury Rears its Head in Our Courts: the Giving of False Testimony Becomes a Grave Problem For Those Whose Task It Is to Administer Justice', New York Times, 10 Jun. 1934, pp. SM7, SM17; and for a fictional account, Evelyn Waugh's A Handful of Dust, London, 1934, ch. 4). If for a brief time the Bishop's Official who presided over the Consistory court did wink at these bigamy cases, it was only a short-lived legal fiction, as they did not become standard legal practice. My thanks to Kenneth Salzberg for pointing out these legal fictions to me.

${ }^{29}$ In the following cases in LMA, MS DL/C/205 where a substantial period of time (over five years, and often as much as twenty years) had elapsed between the time of the allegedly first marriage and 
the name of the bigamist herself, Joan, so that formally at least it was she who sought the dissolution of her second marriage. John Colyn, her allegedly legitimate husband, was neither a party to the suit nor apparently involved in any way. By canon law, Joan should have been restored to John Colyn as his wife, and indeed any marriage that he had made subsequent to his marriage to Joan was also to be dissolved. In a formal sense, that may indeed be what happened (we do not have the actual sentence), but in the depositions, John Colyn functioned as a third party, living in far-enough-away Cambridge, uninvolved in the case and long since departed from Joan's life. This may be, of course, because John Colyn was entirely invented. But that does not solve a more pressing problem: why would Joan Stokton Turnaunt have revealed or even invented such a serious sin, the abrogation of a sacrament, in order to obtain a divorce?

If we consider the divorce suit in light of the classic detective's question, cui bono, our eyes turn not towards Joan, but towards Richard. Richard Turnaunt, a man about forty in 1469 and without a male heir, apparently lost little, if anything, in material terms from the divorce. Subsequent records emanating from the Turnaunt family, such as wills, unsurprisingly omitted any mention of Joan, although the extent of her erasure from the family record is surprising: by 1488 Richard's long-dead first wife, Elizabeth, rather than Joan, was being named as Thomasine's mother. ${ }^{30}$

the case, the plaintiff was the second spouse: Margaret Spyndeler c. William Hathewey (1467), fols. 9rv; Margery Walkelyn c. William Chapman (1468), 19r-20r, 24v, 27v-29r, 30r; William Langton c. Isabel Hamond (1468-69), 23rv, 49v-50v; Robert Eustas c. Puttance Eustas alias Reve (1470), 69v-71v; Alice Couper c. Henry Stowe (1471), 104r-105v; Thomas Baldynge c. Agnes Saunder alias Baldyng (1471), 116v118r, 118v; Thomas Conyngham c. Joan Fordell (1472), 140v-142r. The exceptions, where the bigamist sues, often had unusual circumstances, e.g. Andrew Kynge c. Alice Mylle, 77v-78r, 83rv (1470), which may have arisen from a complaint made to the commissary earlier in 1470 - GL 9064/1, fols. 37r that Andrew Kyng had two wives, both living, a complaint that may have forced him to seek the divorce; or Cecily Swanton c. William Bechynge (1473), fols. 193r-194r, in which the previous spouse conveniently remembered by Cecily Swanton was now dead, although living at the time of the subsequent contract. See also for bigamists as plaintiffs: Richard Buntynge c. Joan Hyldryard (1472), $178 \mathrm{v}-180 \mathrm{v}, 181 \mathrm{v}$ (see above, n. 26 regarding perjury in this case); John Ballard c. Joan Sharpe alias Ballard (1473),182v-183v, 189v-190r. In cases where the first spouse sued for restitution of the marriage, the contracts were usually made in close proximity to each other and to the launch of the suit.

${ }^{30}$ Will of Richard Turnaunt, 1486, TNA, PCC, Prob. 11/7, fols. 193rv; Calendar of the Patent Rolls ... 1485-94, London, 1914, pp. 228-29. As Thomasine was apparently born about 1460 (see above n. 18), she could not have been the daughter of Elizabeth, who died in 1457. In the will of Sir John Risley (Thomasine's husband), TNA, PCC, Prob. 11/17, fols. 60v-61r, even Elizabeth is forgotten in favour of Turnaunt's third wife, Margaret. 
The divorce seems to have allowed Richard to start his life over again, and he married at least once more before his death in $1486 .{ }^{31}$ Although he never had the male heir he presumably wanted, his daughter Thomasine's marriage to Sir John Risley, a courtier of Edward IV and later a knight of the Body to Henry VII, brought his daughter into court circles. ${ }^{32}$ For Joan, on the other hand, the advantages of a divorce that would have been both economically punitive and socially humiliating are harder to see. She would not have been able to remarry, as the sentence would have declared her still married to John Colyn, whom the witnesses declared to be still living, as far as they knew. There is no sign in the case or in other evidence that Joan wanted to, or did, take up with Colyn, if indeed he existed. In my initial reading of the case, I could only hypothesize that Joan was willing to make these considerable sacrifices to escape her marriage to Richard because he was abusive or otherwise unbearable. I changed my mind, however, when I began to look at evidence outside the testimony given in the Consistory court. These other records suggest another possible explanation: that Joan Stokton Turnaunt had nothing to do with the case, even though on paper she was the plaintiff.

We know from many subsequent records more or less what happened to Richard, as I have already related; but we have only one poignant piece of evidence about what happened to Joan. In 1471, two years after the divorce, when John Stokton wrote a long and detailed will, he did not mention his daughter Joan until the very end, in the last sentence. The last several bequests, including the one to Joan, were written in English while the rest of the long will was composed in Latin, suggesting the last bequests were afterthoughts, possibly added at a later date than the composition of the rest of the will (he died in 1473). The last sentence reads: 'To Joan, my daughter, if that she be alive at the hour of my decease, [and if] that it may be understood that she be married or if she have bestowed herself to live in any devout place to serve God, there to lead her life in cleanness, $£ 100$ '. ${ }^{33}$ The phraseology of this bequest implies that her father himself did not know if she was married or unmarried, in a nunnery or leading her life in 'uncleanness,'

\footnotetext{
${ }^{31}$ At his death he was married to Margaret, formerly the wife of John Pye, although it is not clear when they married. TNA, PCC, Prob. 11/7, fol. 193rv.

32 On Risley see Roger Virgoe, 'Sir John Risley (1443-1512), Courtier and Councillor', Norfolk Archaeology 38, 1982, pp. 140-48. Thomasine had had a brief prior marriage to Richard Charlton, another gentleman, but that marriage had been annuled: TNA, C 1/66/286.

${ }^{33}$ TNA, PCC, Prob. 11/6, fols. 71v-75r (quotation at 75r).
} 
that is, as a prostitute or bawd. In short, he apparently did not know what she was doing, or presumably where she was (nunnery or brothel), at the time he composed this bequest.

Joan had evidently lost contact with her birth family by the early 1470 s, perhaps following her 1469 divorce which made her marital and social status so ambiguous. As her father's bequest indicates, in a social sense her two choices following the divorce would have been to resume marriage with her 'real' husband, John Colyn, or enter a nunnery; marrying another man would have been impossible without evidence for the death of John Colyn, and for her father, at least, apparently living life as a single woman would put her beyond the pale. It is possible, however, that her disappearance had taken place long before that, before the divorce, perhaps even as far back as the early 1460s. This might explain why her mother-in-law wrote her will in 1462 in a way that suggested that Richard Turnaunt's marital situation was uncertain, and why Turnaunt told the Chancellor in 1464 that 'good faith and conscience' demanded that John Stokton remove himself from his position as feoffee to the couple's lands. Above all, Joan's abandonment of her marital and natal families could explain why a marriage suit that worked so much to Joan's disadvantage was brought in her name in 1469: maybe she did not bring the suit at all. Suits brought in the name of one person but without their knowledge were far from unknown in fifteenth-century England: the Chancellor heard a number of cases in which women contended that litigation had been undertaken in their names but without their knowledge, consent, or participation. ${ }^{34}$ Given the frequent legal representation of women by proxies, it would not have been difficult to do this. The form that Turnaunt c. Turnaunt took - the neat, detailed, and certain testimony of the witnesses (which included exact dates) and the lack of any counter-evidence - suggests that the suit was being undertaken in such a way that the evidence would be clear and unassailable, a textbook case. If Richard wanted - or, from his point of view, needed - a way of declaring his marriage to Joan to be definitively ended so that he could remarry, a suit fraudulently undertaken in Joan's name but really at Richard's instigation would have been the neatest way to accomplish it. A bigamy suit could have been, more logically should have been, brought by Richard, requesting a divorce from Joan on the grounds of her precontract, but this would have been difficult if she had already disappeared. While a marriage case could proceed even when the defendant

${ }^{34}$ E.g. TNA, C1/66/308, C1/66/353. 
did not respond to a citation or summons to appear in the church court, ${ }^{35}$ Joan's lack of response to the citation might have raised issues Richard preferred to leave dormant. Strategically, then, it would have been in Richard's interest instead to engineer a suit brought in her name, rather than his; if he had sued her, it would have been more obvious that she was not present to answer the suit. There is no record that either Joan or Richard ever appeared in the Consistory court; in Consistory court litigation parties were usually represented by proctors, and it was possible, although probably uncommon, for the parties not to appear before the court at all. ${ }^{36}$ If Joan's relatives were ignorant of the suit, or simply let it go out of embarrassment or anger with her, this strategem could have, and perhaps did, work.

What happened to Joan Stokton we will almost certainly never know. The scenario I presented above of Joan's disappearance and Richard's construction of a false suit is hypothetical, and almost certainly unprovable but I believe it is the most plausible of the various scenarios I can construct from the evidence I have uncovered about the case and those involved in it. It is certainly more plausible than the story reconstructible from the documents from the Consistory case alone.

My experience chasing down the records that related to Joan Stokton, Richard Turnaunt, and those connected to them have resembled in all-toouncanny ways the fictional processes of detection: I went down many wrong paths, spent far too much time chasing down the wrong people, and experienced several exciting epiphanic moments when I dug up a crucial connection. I conceptualized the 'facts' of the case in many different ways before arriving at the scenario that I have unveiled here, in Hercule Poirot fashion. Were I addressing a drawing room that included the guilty parties, I might be able to startle a confession from Richard Turnaunt by the brilliance of my deductions. But I am neither a golden-age detective, nor a golden-age historian.

As historians, we pride ourselves on our empiricism: we derive our arguments from archival, textual, and material evidence. The epistemic problem for a discipline that relies on what can be documented, however, is

\footnotetext{
${ }^{35}$ Helmholz, Marriage Litigation, p. 124.

${ }^{36}$ Ibid.
} 
that what is documentable is sometimes false, and indeed deliberately written so as to deceive. While obviously none of the records used here were written with the $21^{\text {st }}$-century historian in mind, they were written with the archive in mind. To use a fifteenth-century word, they were memoranda, things which are to be remembered (and by extension, things which are to displace other things which are to be forgotten). As Derrida suggests, the Archive induces amnesia as well as remembering. ${ }^{37}$ In one sense, the written record then becomes what happened; as Carolyn Steedman says, the archive is in the future perfect tense - what is written is what will have been. ${ }^{38}$ When in 1488, Sir John and Thomasina Risley named Richard and Elizabeth Turnaunt as Thomasina's parents, ${ }^{39}$ they sought to efface Joan Stokton Turnaunt's existence from the record, and, in this one document at least, Joan's maternity disappeared. A record's 'factual' status, its ability to become what-will-have-been, may also have to suffer competition from other versions - other documents that suggest the impossibility of Elizabeth's maternity, for instance - creating fissures and disjunctures into which later historians can burrow. Each new document, discovered partly through diligence but also partly through luck, casts each of the previous bits of evidence in a new light, in effect changing their meanings. For this reason, the meaning can only ever be unstable and temporary $^{40}$ : while possibly no further clues about Joan Stokton will be uncovered by me or by anyone else, something else could surface and throw the meaning I have here established out the window. ${ }^{41}$

Thinking about how the documents were recorded and archived not only destabilizes their meanings, but it also suggests a way to come out the other side of the epistemological dilemma about what the historical evidence can tell us. Late medieval English people used documents, as well as the legal processes in which those documents were employed and produced, in

\footnotetext{
${ }^{37}$ Steedman, Dust, pp. 4-5; Derrida, Archive Fever, p. 11.

${ }^{38}$ Derrida, Archive Fever, p. 9; Steedman, Dust, p. 7.

${ }^{39}$ CPR, 1485-94, pp. 228-29.

${ }^{40}$ Farge's formulation of how to write this instability is thoughtful: Farge, Goût de l'archive, pp. 145 48.

${ }^{41}$ As I was finishing final revisions for this article, I came across a 1470 reference to a Joan Stokton, nun in the Dominican nunnery at Dartford (John Dunkin, The History and Anquities of Dartford, London, 1844, pp. 126-27), and I thought perhaps I had, belatedly, found the answer to Joan's last days. This Joan Stokton, however, is the daughter of Thomas Stoughton, fishmonger of London (ibid.; Will of Thomas Stoughton, 1478, TNA, PCC Prob. 11/7, fols. 23r-23v).
} 
complex and sophisticated ways. Law was not only a framework through which the church, crown, and city could police, authenticate, and supervise personal relationships such as marriage, but it was also a tool that could be wielded by skilful practitioners, professional and lay, to achieve their own ends. The law was sometimes flexible, vulnerable to influence. This flexibility made it integral to the complex workings of late medieval English social and political processes. Richard Turnaunt may have been able to manipulate the divorce case, against legal right, simply because he had greater political, social, and legal influence. ${ }^{42}$ Thus if the archived documents that accompanied the workings of the law are a less straightforward empirical basis for our knowledge of the past than historians have sometimes assumed, those documents, viewed from a slightly different angle, provide remarkable evidence precisely for those legal, political, and archival processes.

Yet crucially important aspects of the past remain occluded, and it is hard to see how they can be reached through empirical methods. It is comparatively easy to hypothesize about how medieval documents functioned when they were wielded in rational ways that maximized the economic, political, or social self-interest of the wielders. What remains less easy to infer are actions motivated by unreason or emotion, or by a different kind of selfinterest that cannot be measured by economic or political advantage. My thinking about the Turnaunt case has privileged scholars' arguments about the greater legal and political savoir-faire manhood conferred as well as assumptions about Richard's self-interest - the aristocrat's need for a male heir, his desire (only to be expected in his circumstances) to rid himself of a wife who was barren and possibly even absent. Still remaining veiled, accessible only through speculation, are the reasons for the marriage's breakdown and Joan's disappearance: Joan may have descended into serious mental illness, or Richard may have been physically or mentally abusive, or they may simply have intensely disliked one another. But perhaps I am wrong that Richard manipulated the case. If Joan did indeed voluntarily bring the

42 This was not the way it always went: the principles of the law could sometimes prove unexpectedly obdurate. Some fifteenth-century men and women were able to use the remarkable powers that medieval canon law gave to individuals in the making of marriage to defeat those who otherwise held all the cards of power and influence. An obvious example of this is the failed attempt by the Paston family to annul the marriage of Margery Paston (sister of John II and John III) to the family bailiff Richard Calle; all their best efforts to influence the bishop of Norwich's decision came to nought, as he could not deny the couple their canonical right to make a marriage. Norman Davis, ed., The Paston Letters and Papers of the Fifteenth Century, 2 vols., Oxford, 1971, 1976, vol. 1, pp. 341-44, 351, 408-10, 541-42. 
suit herself, as the records state, she used litigation not to advance socially, politically, or economically, as did many other late medieval litigants, but in fact to fall quite precipitously out of a marriage with a gentleman, into a life cut off from her marital and natal families. It may have been worth it to her to be free of the marriage, for reasons that may, or may not, have been rational, even though divorcing Richard evidently meant losing both her daughter and her own birth family. Either way, Joan's case highlights one of the difficulties facing us as historians, for we often depend, sometimes unconsciously, upon our assumptions about rational strategies of social negotiation to make narrative connections between the scattered bits of evidence out of which we write our history. The end of Joan's life, as far as I know, is not documented, leaving us only with speculative imaginings. It is hard to imagine, however, that her days ended happily. 